Article

\title{
Agronomic Comparisons of Organic and Conventional Soybean with Recommended and High Inputs during the First 4 Years of Organic Management
}

\author{
William Cox ${ }^{1, * \mathbb{D}}$, Jerome Cherney ${ }^{1}$ and Mark Sorrells ${ }^{2}$ \\ 1 Unit of Soil and Crop Sciences, School of Integrated Plant Sciences, Cornell University, Ithaca, NY 14853, \\ USA; jhc5@cornell.edu \\ 2 Unit of Plant Breeding and Genetics, School of Integrated Plant Sciences, Cornell University, Ithaca, \\ NY 14853, USA; mes12@cornell.edu \\ * Correspondence: wjc3@cornell.edu; Tel.: +1-607-255-1758
}

Received: 7 August 2019; Accepted: 26 September 2019; Published: 1 October 2019

\begin{abstract}
Organic soybean hectares will increase in the Northeast United States of America (USA) because of demand by the expanding organic dairy industry. We evaluated organic and conventional soybean with recommended and high inputs (high seeding rate + organic seed treatment in organic system) from 2015 to 2018 in New York, USA to determine if high input management could reduce the yield penalty in organic soybean. Organic compared with conventional soybean yielded similarly in 2015 and 2016 but $\approx 11 \%$ lower in 2017 and 2018. Organic compared with conventional soybean had similar early and harvest plant densities in 2017 but lower early and harvest plant densities in 2018 when both densities correlated with yield ( $r=0.33$ and 0.36 , respectively). Weed densities in organic soybean were low ( $<0.77$ weeds $/ \mathrm{m}^{2}$ in all years). Nevertheless, organic compared with conventional soybean in 3 of 4 years had greater weed densities, which had significant negative correlations with yield in $2015(r=-0.36), 2017(r=-0.53)$ and $2018(r=-0.36)$. Organic compared with conventional soybean mostly had fewer pods/plant and greater seed weight but yield components showed no consistent correlations with yield. Organic soybean had similar weed densities and yield with recommended and high input management in all years indicating that growers should probably plant organic soybean at recommended seeding rates $(370,500$ seeds/ha) during the first 4 years of organic production under similar environmental conditions of this study.
\end{abstract}

Keywords: soybean; organic system; plant densities; weed densities; yield components

\section{Introduction}

Organic soybean (Glycine max (L.) Merr.) production in the USA increased from $\approx 40,000$ ha in 2008 to $\approx 50,000$ ha in 2016 [1]. Organic soybean production, however, lags behind the $\approx 87,000$ ha of organic maize (Zea mays L.) for grain and the $\approx 136,000$ ha of organic wheat (Triticum aestivum L.), the other major field crops in the USA [1]. Organic soybean fixes most of its $\mathrm{N}$ so does not rely on available soil $\mathrm{N}$ from organic fertilizer to meet its $\mathrm{N}$ requirement; a major constraint to the production of organic maize and organic wheat. Nevertheless, a USDA survey reported a yield penalty of $34 \%$ for organic soybean compared to $27 \%$ for organic maize and $32 \%$ for organic wheat [2]. Despite the yield penalty, organic soybean hectares will increase because of the growing demand for organic soybean by the expanding organic dairy industry; the dominant agricultural sector in the Northeast USA [3]. Furthermore, organic compared with conventional soybean production is more profitable because the current organic price premium offsets the yield penalty and greater production costs [4]. 
The organic soybean price premium could decrease, however, as more growers and hectares convert to organic production. Consequently, more agronomic research is required to identify organic soybean management practices that reduce the yield penalty, especially if the organic price premium decreases in the future.

Most studies on organic soybean have been conducted in the Midwest USA. Organic soybean in an organic maize soybean-wheat/red clover (Trifolium pratense L.) rotation produced a yield $\approx 90 \%$ of conventional soybean in a conventional maize-soybean rotation in a 1990-2002 study at two sites in Wisconsin, USA [5]. In wet years, however, organic soybean produced a yield only $\approx 74 \%$ of conventional soybean because of challenges in implementing timely mechanical weed control practices in organic soybean. In a study in Minnesota, USA from 1992-2007, organic soybean produced a yield $69 \%$ of conventional soybean in a soybean-maize rotation [6]. As in the Wisconsin study, organic compared with conventional soybean yield was much lower in wet years because of increased weed interference, associated with greater challenges for timely mechanical weed control practices. In another Minnesota study from 2002 to 2005, organic compared with conventional soybean produced a yield $\approx 15 \%$ lower in a maize-soybean rotation [7]. In a study in Iowa, USA from 1998-2001, however, organic soybean in a maize-soybean-oat/alfalfa rotation had similar weed densities, mostly similar soybean densities and similar yield compared to conventional soybean in a maize-soybean rotation [8]. In the second phase of the same study from 2002 to 2010, organic compared with conventional soybean in their respective rotations once again had similar weed densities, soybean densities and yield [9]. In a study in the Eastern USA in Maryland from 2001 to 2005, organic compared with conventional soybean in a maize-soybean-wheat/red clover rotation produced $\approx 19 \%$ lower yield [10]. Most of the yield differences between organic and conventional soybean in this study were associated with greater weed densities in the row of organic soybean. In the same study from 2006 to 2014, organic compared with conventional soybean yielded $38 \%$ lower, excluding the year when organic soybean could not be harvested because of overwhelming weed interference [11].

The lower yield in organic compared to conventional soybean yield is mostly associated with weed interference [4-7,10-12]. The use of extended crop rotations, however, can reduce weed seedbanks, which may improve weed control in organic soybean production [13]. For example, the weed seedbanks of common lambsquarters (Chenopodium album L.) and smooth pigweed (Amaranthus hybridus L.) were $\approx 4 \times$ to $5 \times$ lower at the beginning of the growing season in a soybean-wheat-maize rotation compared to a soybean-maize rotation. Likewise, the use of increased seeding rates in organic soybean has been reported to reduce weed densities and increase yield [14,15]. We conducted a 4-year study comparing organic and conventional soybean in a soybean-wheat/red clover-maize rotation with recommended and high inputs. The objective of the study was to determine if organic soybean in a soybean-wheat/red clover-maize rotation with high input (organic seed treatment and high seeding rates) compared with recommended input management would reduce weed densities, thereby increase yield and reduce the yield penalty when compared with conventional soybean. A second objective was to examine the yield components (pods/plant, seeds/pod and seed weight) to observe how organic soybean responds to environmental conditions and management practices. To the best of our knowledge, yield component responses by organic soybean have not been reported in the literature.

\section{Materials and Methods}

We initiated a study at a Cornell University research farm near Aurora, New York $\left(42^{\circ} 44^{\prime} \mathrm{N}\right.$, $76^{\circ} 40^{\prime} \mathrm{W}$ ) in 2015 to evaluate three sequences of the soybean maize-wheat/red clover rotation under conventional and organic farming systems (Table 1). Unfortunately, we were unable to plant wheat after soybean in 2017 because of wet fall conditions. Consequently, we planted maize, which resulted in a maize-soybean rotation as one of the rotations (Table 1). 
Table 1. Sequence of the red clover-maize-soybean-wheat/red clover (Cl-M-S-W/Cl), maize-soybean (M-S-M-S) and soybean-wheat/red clover-maize-soybean (S-W/Cl-M-S) rotations from 2015 to 2018 at a Cornell University Research Farm in central New York, USA.

\begin{tabular}{cccc}
\hline \multirow{2}{*}{ Year } & \multicolumn{3}{c}{ Crop Rotations } \\
\cline { 2 - 4 } & Cl-M-S-W/Cl & M-S-M-S & S-W/Cl-M-S \\
\hline 2015 & Red Clover $(\mathrm{Cl})$ & Maize & Soybean \\
2016 & Maize & Soybean & Wheat/RC \\
2017 & Soybean & Maize & Maize \\
2018 & Wheat $/(\mathrm{Cl})$ & Soybean & Soybean \\
\hline
\end{tabular}

Three contiguous experimental fields ( $216 \mathrm{~m} \times 40 \mathrm{~m}$ each), which had been farmed conventionally and had a mixture of silt loam soils (fine-loamy, mixed, mesic, Glossoboric Hapludalfs and fine-loamy, mixed, mesic Oxyaquic Hapludalfs) were used for the study. The three contiguous fields, $40 \mathrm{~m}$ long and $216 \mathrm{~m}$ wide, had different cropping histories so they had different previous crops (barley (Hordeum vulgare L.), maize and soybean) in 2014. The experimental design was a randomized complete block (four replications) in a split-split plot arrangement with previous crops or fields as whole plots, farming systems (conventional and organic) as sub-plots and management inputs (recommended and high inputs) as sub-sub plots.

Soybean (and maize) areas in the three fields, determined each year by the rotation sequences in conventional and organic farming systems, were moldboard plowed around 20 May in all years, followed by one secondary tillage operation (culti-mulch) the following day. Organic and conventional soybean plots were planted immediately after secondary tillage along the entire $40 \mathrm{~m}$ length of each field. We first planted organic soybean in $0.76 \mathrm{~m}$ row spacing (wider spacing for inter-row cultivation purposes) with a $4.5 \mathrm{~m}$ White split-row planter (Coldwater, OH, USA) with inter-units disengaged. We then planted conventional soybean plots in the typical $0.38 \mathrm{~m}$ row spacing for soybean in this environment with the same planter with inter-units engaged. After soybean emergence, we marked off $3.5 \mathrm{~m}$ borders on the north and south sides of the plots so plot length was shortened to $33 \mathrm{~m}$ in each field. We also planted $3 \mathrm{~m}$ border strips between sub-plots (farming systems) so herbicide or fungicide sprays would not drift from conventional into organic soybean. Whole plot the three fields) dimensions were $216 \mathrm{~m}$ wide and $33 \mathrm{~m}$ long, sub-plot (farming systems) dimensions were 27 $\mathrm{m}$ wide and $33 \mathrm{~m}$ long within each field and sub-subplot (management inputs) dimensions were 3 $\mathrm{m}$ wide and $33 \mathrm{~m}$ long within each field. Precipitation and temperature data were collected daily at a Weather Station (National Weather Service, Silver Spring, MD, USA) located between two of the contiguous fields.

Table 2 lists the management practices for conventional and organic soybean for the 4 years of this study. We looked for a non-GM isoline to the conventional GM variety as the organic variety so we could eliminate genetic differences between farming systems, as we did with maize and wheat in this study $[16,17]$. Unfortunately, we could not find an isoline of a GM variety so we used a GM and non-GM variety from the same seed company (Pioneer, Hi-Bred, IA, USA) with similar maturity (Maturity Group II.2) and yield potential but different genetics. Also, we had to switch the organic variety in the 4th year of the study because the non-GM variety used in the previous 3 years was no longer available from the seed company. Major differences between conventional and organic soybean management included (a) a GM variety, P22T41R2 (with an insecticide/fungicide seed treatment), which has RR2Y and SCN traits, versus a non-GM variety, P92Y21, from 2015 to 2017 and P21A20 in 2018; (b) $0.38 \mathrm{~m}$ versus $0.76 \mathrm{~m}$ row spacing ( $0.76 \mathrm{~m}$ for cultivation of weeds in organic soybean); and (c) a single Glyphosate herbicide application for weed control versus tine weeding (2015) or rotary hoeing (2016-2018), followed by close cultivation to the row, followed by three additional cultivations between the rows, respectively. Seeding rates of 370,500 and 494,000 seeds/ha were used for recommended and high input management treatments in both farming systems. Conventional soybean in the high input treatment also received a fungicide (Fluxapyroxad + Pyraclostrobin at $\approx 300 \mathrm{~mL} / \mathrm{ha}$ ) application 
at the beginning pod to full pod stage (R3-R4 stage) in late July for the control of potential diseases. An organic seed treatment, Sabrex (strains of Trichoderma, a soil-dwelling fungus), was added to the seed hopper and mixed into the high input treatment of organic soybean. We did not fertilize soybean because conventional soybean growers in our region typically do not use fertilizer on soybean.

Table 2. Row spacing, planting rate, seed treatment, cultivar, herbicide, rotary hoeing, cultivation and fungicide application for soybean in conventional and organic farming systems with two management inputs (recommended and high input) from 2015 to 2018 at a University Research Farm in central New York, USA.

\begin{tabular}{ccccc}
\hline \multirow{2}{*}{ Descriptor } & \multicolumn{2}{c}{ Conventional } & \multicolumn{2}{c}{ Organic } \\
\cline { 2 - 5 } & Recommended & High & Recommended & High \\
\hline Row Spacing (m) & 0.38 & 0.38 & 0.76 & 0.76 \\
Planting rate (seeds/ha) & 370,500 & 494,000 & 370,500 & 494,000 \\
Seed Treatment & \multicolumn{2}{c}{ Fungicide/insecticide } & None & Sabrex \\
\hline Cultivar & P22T41RR2 & 92 Y21/P21A20 \\
Herbicide & Glyphosate 1 & None \\
Rotary Hoeing & None & $1 \times$ \\
Cultivation & None & $4 \times$ \\
Fungicide & Fluxapyroxad/Pyraclostrobin & None \\
\hline
\end{tabular}

Early soybean densities were estimated about 10-15 days after emergence by counting all soybean plants along a $1 \mathrm{~m}$ length in the harvest rows ( 2 center rows in conventional soybean and 4 center rows in organic soybean) in six regions of each plot. Weed densities were also determined by counting all visible weeds along the entire width of the $33 \mathrm{~m}$ length of the plot at the beginning of the seed-filling stage (R5), the end of the critical weed-free period in soybean in this environment [18]. Predominant weed species, which did not differ among previous crops or between farming systems, included wild buckwheat (Polygonum convovulus L.); common lambsquarters (Chenopodium album L.); barnyardgrass (Echinochloa crus-gall L.); Pennsylvania smartweed (Polygonum pensylvanicum L.); green foxtail (Setaria vidis L.); common ragweed (Ambrosia artemisifolia L.) and red root pigweed (Amaranthus retroflexus L.). Leaf disease ratings were taken from full pod to the full seed stage (R6) but will not be reported because of negligible observed symptoms.

Yield components were determined a few days before harvest by hand-harvesting all the plants along a $1 \mathrm{~m}$ length of the 4 harvest rows of conventional soybean and 2 harvest rows of organic soybean every $10 \mathrm{~m}$ along the plot length for a total of three samples. Whole plants were then air-dried in a greenhouse for a couple of weeks. Plants from each sample were first weighed and then counted. Next, all the pods on each plant were counted to determine pods/plant. The pods were run through a stationary plot combine to thresh the seed from the pods and then run through a seed cleaner. The seed was then counted with a seed counter (Old Mill Co., Savage, MD, USA) and divided by pod number to calculate seeds/pod. All the seeds were weighed and divided by seed number to calculate individual soybean seed weight. We calculated the harvest index by dividing the total seed weight by the total plant weight. Unfortunately, the first 30 plant samples were inadvertently not weighed in 2018 so only 2015 to 2017 harvest index values will be presented.

Soybean was harvested in late September in 2015, 2017 and 2018, and in early November in 2016, with a $1.5 \mathrm{~m}$ wide small plot Almaco combine (Nevada, IA, USA). We harvested the three $10 \mathrm{~m}$ remaining lengths in each soybean plot (after removing plants for yield component analyses) and pooled the three samples. An approximate $1000 \mathrm{~g}$ sample was collected from each $10 \mathrm{~m}$ harvest length to obtain two seed moisture estimates. Yield was adjusted to $13.0 \%$ moisture.

The Bartlett test $(p=0.01)$ indicated that variances were not homogeneous across years for yield, early soybean densities, harvest soybean densities, pods/plant, seeds/pod and seed weight. Also, we only had 3 years of harvest index values and the organic soybean variety was different in the 4 th 
year compared to the first 3 years of the study. In addition, the cropping history of soybean differed during the first 3 years, as we established the rotations in this study. Consequently, we analyzed each year separately. Although soybean yield in the two rotations in 2018 did not differ, we present the statistical analysis of soybean only in the soybean-wheat/red clover-maize rotation (and not the maize-soybean rotation) in this manuscript to conform to the original objective of evaluating soybean in the soybean-wheat/red clover-maize rotation. Previous crops (three contiguous fields), farming systems (conventional and organic) and management inputs (recommended and high) were considered fixed and replications random for statistical analyses of yield, early and harvest soybean densities, weed densities, harvest index and yield components for each year, using the Residual Maximum Likelihood (REML) function in the MIXED procedure of SAS (version 9.4; SAS Institute Inc., Cary, NC, USA). Previous crops had early and harvest soybean density effects $(p=0.03)$, a weed density effect $(p=0.02)$ and a seed weight effect in $2015(p=0.04)$ but there were no interactions with farming systems or inputs in 2015 (Table 3). From 2016 to 2018, there were no previous crop effects or interactions with farming systems or inputs for any measured variables. Consequently, the data were pooled across the three contiguous fields in all 4 years. Least square means of the main effects (farming system and management inputs) were computed and means separations were performed on significant effects using Tukey's Studentized Range test (HSD) with statistical significance set at $p<0.05$. Differences among least square means for farming system interactions were calculated also using Tukey's HSD test. Two-way way interactions were detected for many measured variables so the interaction comparisons are presented in the tables. We provided the standard error of the mean for the farming systems $x$ input management interaction in the tables. Simple correlations (Pearson) among all measurements within each year were calculated using PROC CORR in SAS (Table 4). 
Table 3. $P$-values for yield, early plant density, weed density, harvest plant density, harvest index, pods/plant, seeds/pod and seed weight in $2015,2016,2017$ and 2018 on a University research farm in central New York, USA.

\begin{tabular}{|c|c|c|c|c|c|c|c|c|}
\hline Variable & Yield & Early Plant Density & Weed Density & Harvest Plant Density & Harvest Index & Pods/Plant & Seeds/Pod & Seed Wt. \\
\hline \multicolumn{9}{|c|}{2015} \\
\hline Previous Crop (PC) & 0.06 & 0.03 & 0.02 & 0.03 & 0.24 & 0.20 & 0.78 & 0.04 \\
\hline Farming System (FS) & 0.10 & 0.04 & $<0.001$ & 0.31 & 0.22 & $<0.001$ & $<0.001$ & $<0.001$ \\
\hline $\mathrm{PC} \times \mathrm{FS}$ & 0.07 & 0.38 & 0.14 & 0.39 & 0.10 & 0.89 & 0.08 & 0.08 \\
\hline Inputs (I) & 0.001 & $<0.001$ & $<0.001$ & $<0.001$ & 0.28 & $<0.001$ & 0.001 & 0.01 \\
\hline $\mathrm{PC} \times \mathrm{I}$ & 0.10 & 0.74 & 0.19 & 0.47 & 0.28 & 0.20 & 0.66 & 0.74 \\
\hline $\mathrm{FS} \times \mathrm{I}$ & 0.03 & 0.005 & $<0.001$ & 0.10 & 0.18 & 0.02 & 0.33 & 0.003 \\
\hline $\mathrm{PC} \times \mathrm{FS} \times \mathrm{I}$ & 0.62 & 0.89 & 0.12 & 0.14 & 0.42 & 0.28 & 0.12 & 0.99 \\
\hline \multicolumn{9}{|c|}{2016} \\
\hline Previous Crop (PC) & 0.09 & 0.24 & 0.82 & 0.72 & 0.26 & 0.29 & 0.19 & 0.20 \\
\hline Farming System (FS) & 0.11 & $<0.001$ & 0.05 & 0.004 & $<0.001$ & 0.05 & 0.04 & $<0.001$ \\
\hline $\mathrm{PC} \times \mathrm{FS}$ & 0.62 & 0.11 & 0.77 & 0.17 & 0.58 & 0.21 & 0.38 & 0.26 \\
\hline Inputs (I) & 0.22 & $<0.001$ & 0.14 & $<0.001$ & 0.24 & $<0.001$ & 0.50 & 0.25 \\
\hline $\mathrm{PC} \times \mathrm{I}$ & 0.20 & 0.21 & 0.45 & 0.79 & 0.18 & 0.56 & 0.63 & 0.49 \\
\hline $\mathrm{FS} \times \mathrm{I}$ & 0.06 & $<0.001$ & 0.97 & 0.27 & 0.29 & 0.08 & 0.10 & 0.01 \\
\hline $\mathrm{PC} \times \mathrm{FS} \times \mathrm{I}$ & 0.30 & 0.16 & 0.52 & 0.65 & 0.82 & 0.94 & 0.46 & 0.21 \\
\hline \multicolumn{9}{|c|}{2017} \\
\hline Previous Crop (PC) & 0.33 & 0.10 & 0.09 & 0.30 & 0.71 & 0.17 & 0.45 & 0.56 \\
\hline Farming System (FS) & 0.001 & 0.009 & $<0.001$ & 0.21 & 0.87 & $<0.001$ & $<0.001$ & $<0.001$ \\
\hline $\mathrm{PC} \times \mathrm{FS}$ & 0.93 & 0.66 & 0.61 & 0.51 & 0.07 & 0.11 & 0.31 & 0.09 \\
\hline Inputs (I) & 0.03 & $<0.001$ & 0.54 & $<0.001$ & 0.02 & $<0.001$ & 0.001 & $<0.001$ \\
\hline $\mathrm{PC} \times \mathrm{I}$ & 0.68 & 0.39 & 0.44 & 0.70 & 0.52 & 0.61 & 0.11 & 0.45 \\
\hline $\mathrm{FS} \times \mathrm{I}$ & 0.77 & 0.20 & 0.91 & 0.73 & 0.10 & 0.06 & 0.03 & 0.03 \\
\hline $\mathrm{PC} \times \mathrm{FS} \times \mathrm{I}$ & 0.99 & 0.46 & 0.72 & 0.37 & 0.47 & 0.91 & 0.14 & 0.14 \\
\hline \multicolumn{9}{|c|}{2018} \\
\hline Previous Crop (PC) & 0.12 & 0.50 & 0.68 & 0.60 & - & 0.07 & 0.08 & 0.09 \\
\hline Farming System (FS) & 0.02 & $<0.001$ & 0.11 & 0.005 & - & 0.004 & $<0.001$ & $<0.001$ \\
\hline $\mathrm{PC} \times \mathrm{FS}$ & 0.16 & 0.26 & 0.40 & 0.48 & - & 0.49 & 0.16 & 0.19 \\
\hline Inputs (I) & 0.01 & 0.03 & 0.78 & $<0.001$ & - & $<0.001$ & 0.001 & $<0.001$ \\
\hline $\mathrm{PC} \times \mathrm{I}$ & 0.24 & 0.41 & 0.71 & 0.37 & - & 0.06 & 0.41 & 0.75 \\
\hline $\mathrm{FS} \times \mathrm{I}$ & 0.37 & $<0.001$ & 0.002 & $<0.001$ & - & $<0.001$ & 0.20 & 0.002 \\
\hline $\mathrm{PC} \times \mathrm{FS} \times \mathrm{I}$ & 0.15 & 0.54 & 0.37 & 0.08 & - & 0.45 & 0.14 & 0.30 \\
\hline
\end{tabular}


Table 4. Correlations ( $r$-values) among seed yield, early plant density, weed density, harvest plant density, pods/plant, seeds/pod and seed weight of soybean from 2015 to 2018 at a University Research Farm in central New York, USA.

\begin{tabular}{|c|c|c|c|c|c|c|c|c|}
\hline Variable & Yield & Early Plant Density & Weed Density & Harvest Plant Density & Harvest Index & Pods/Plant & Seeds/Pod & Seed Wt. \\
\hline \multicolumn{9}{|c|}{$2015(n=48)$} \\
\hline Yield & - & 0.31 & -0.36 & NS & 0.40 & NS & NS & NS \\
\hline Early plant Density & $0.31^{+}$ & - & NS & 0.87 & NS & -0.68 & NS & 0.28 \\
\hline Weed density & -0.36 & NS & - & NS & NS & NS & 0.46 & 0.50 \\
\hline Harvest plant density & NS & 0.87 & NS & - & NS & -0.71 & NS & NS \\
\hline Harvest Index & 0.40 & NS & NS & NS & - & NS & 0.41 & 0.43 \\
\hline Pods/plant & NS & -0.68 & NS & -0.71 & NS & - & -0.38 & -0.55 \\
\hline Seeds/pod & NS & NS & 0.46 & NS & 0.41 & -0.38 & - & 0.70 \\
\hline Seed wt. & NS & 0.28 & 0.50 & NS & 0.43 & -0.55 & 0.70 & - \\
\hline \multicolumn{9}{|c|}{$2016(n=48)$} \\
\hline Yield & - & NS & NS & NS & NS & NS & NS & NS \\
\hline Early plant density & NS & - & -0.33 & 0.75 & NS & -0.47 & 0.45 & NS \\
\hline Weed density & NS & -0.33 & - & NS & NS & NS & NS & NS \\
\hline Harvest plant density & NS & 0.75 & NS & - & NS & -0.70 & NS & NS \\
\hline Harvest Index & NS & NS & NS & NS & - & 0.51 & NS & -0.68 \\
\hline Pods/plant & NS & -0.47 & NS & -0.70 & 0.51 & - & NS & -0.46 \\
\hline Seeds/pod & NS & 0.45 & NS & NS & NS & NS & - & 0.29 \\
\hline Seed wt. & NS & NS & NS & NS & -0.68 & -0.46 & 0.29 & - \\
\hline \multicolumn{9}{|c|}{$2017(n=48)$} \\
\hline Yield & - & NS & -0.53 & NS & NS & 0.52 & -0.31 & -0.44 \\
\hline Early plant density & NS & - & -0.33 & 0.62 & NS & -0.66 & 0.40 & 0.47 \\
\hline Weed density & -0.53 & -0.33 & - & NS & NS & -0.41 & 0.53 & 0.40 \\
\hline Harvest plant density & NS & 0.62 & NS & - & NS & -0.64 & NS & 0.35 \\
\hline Harvest Index & NS & NS & NS & NS & - & 0.31 & NS & NS \\
\hline Pods/plant & 0.52 & -0.66 & -0.41 & -0.64 & 0.31 & - & -0.67 & -0.67 \\
\hline Seeds/pod & -0.31 & 0.40 & 0.53 & NS & NS & -0.67 & - & 0.74 \\
\hline Seed wt. & -0.44 & 0.47 & 0.40 & 0.35 & NS & -0.67 & 0.74 & - \\
\hline \multicolumn{9}{|c|}{$2018(n=48)$} \\
\hline Yield & - & 0.33 & -0.36 & 0.39 & - & NS & 0.42 & -0.34 \\
\hline Early plant density & 0.33 & - & -0.20 & 0.70 & - & -0.43 & 0.22 & -0.31 \\
\hline Weed density & -0.36 & -0.20 & - & NS & - & -0.33 & -0.61 & 0.72 \\
\hline Harvest plant density & 0.39 & 0.70 & NS & - & - & -0.70 & NS & NS \\
\hline Pods/plant & NS & -0.43 & -0.33 & -0.70 & - & - & 0.38 & -0.46 \\
\hline Seeds/pod & 0.42 & 0.22 & -0.61 & NS & - & 0.38 & - & -0.82 \\
\hline Seed wt. & -0.34 & -0.31 & 0.72 & NS & - & -0.46 & -0.82 & - \\
\hline
\end{tabular}




\section{Results}

Weather conditions differed markedly among growing seasons with total rainfall ranging from 255 to $454 \mathrm{~mm}$ and average temperatures ranging from 18.0 to $19.9^{\circ} \mathrm{C}$ (Table 5). The 2015 and 2017 growing seasons had wet May and June conditions (161 and $46 \mathrm{~mm}$ above average, respectively); whereas the 2016 and 2018 growing seasons had dry May and June conditions (93 and $91 \mathrm{~mm}$ below average, respectively). The 2015 growing season had dry July and August conditions ( $71 \mathrm{~mm}$ below average), the time when soybean is in the flowering (R1-R2) to full-seed (R6) stage and thus most vulnerable to water stress [19]. In contrast, the 2017 and 2018 growing seasons had wet July and August conditions ( $48 \mathrm{~mm}$ and $56 \mathrm{~mm}$ above average). Overall, the 2016 growing season had the least amount of precipitation (105 mm below average), the 2017 growing season was the coolest $\left(1.1^{\circ} \mathrm{C}\right.$ below normal) and the 2018 growing season was the warmest $\left(0.8^{\circ} \mathrm{C}\right.$ above normal).

Table 5. Monthly and total precipitation and monthly and average temperature during the soybean growing season in 2015, 2016, 2017 and 2018 and the 30-year average at a University Research Farm in central New York, USA.

\begin{tabular}{ccccccccccc}
\hline \multicolumn{1}{c}{ Precipitation $(\mathbf{m m})$} \\
\hline Month & $\mathbf{2 0 1 5}$ & $\mathbf{2 0 1 6}$ & $\mathbf{2 0 1 7}$ & $\mathbf{2 0 1 8}$ & $\mathbf{3 0 - y r}$ avg. & $\mathbf{2 0 1 5}$ & $\mathbf{2 0 1 6}$ & $\mathbf{2 0 1 7}$ & $\mathbf{2 0 1 8}$ & $\mathbf{3 0 - y r . a v g .}$ \\
\hline May & 142 & 63 & 133 & 52 & 80 & 17.2 & 13.6 & 12.9 & 16.7 & 14.2 \\
June & 203 & 28 & 97 & 41 & 104 & 17.8 & 18.2 & 18.7 & 18.6 & 19.3 \\
July & 71 & 48 & 186 & 142 & 84 & 20.4 & 22.1 & 20.8 & 22.4 & 21.8 \\
August & 34 & 116 & 38 & 90 & 92 & 19.7 & 22.8 & 19.5 & 21.8 & 20.9 \\
Total/Avg. & 450 & 255 & 454 & 325 & 360 & 18.8 & 19.3 & 18.0 & 19.9 & 19.1 \\
\hline
\end{tabular}

Soybean yield had a farming system $\times$ input management interaction in 2015, no significant differences in 2016 and farming system and input management effects in 2017 and 2018 (Table 3). Organic compared with conventional soybean with recommended inputs yielded the same in 2015 but conventional soybean with high inputs produced a yield that was $\approx 10.5 \%$ greater compared to the other three treatments (Table 6). When averaged across input treatments, organic compared with conventional soybean produced a yield that was $\approx 11 \%$ lower in 2017 and 2018. Organic soybean did not respond to high input management in any year of this study and conventional soybean responded only in 2015.

Table 6. Seed yield, early soybean plant density ( 2 weeks after planting), weed density (at the full pod stage) and harvest soybean plant density in 2015, 2016, 2017 and 2018 under conventional (Convent.) and organic farming systems with recommended and high input management at a University Research Farm in central New York, USA.

\begin{tabular}{|c|c|c|c|c|c|c|c|c|}
\hline \multirow{2}{*}{$\begin{array}{l}\text { Treatment } \\
\text { Convent. }\end{array}$} & \multicolumn{4}{|c|}{ Yield (kg/ha) } & \multicolumn{4}{|c|}{ Early Plant Density (Plants $/ \mathrm{m}^{2}$ ) } \\
\hline & 2015 & 2016 & 2017 & 2018 & 2015 & 2016 & 2017 & 2018 \\
\hline Recommended & $3006 b^{+}$ & 2737 a & $3962 a$ & 3919 a & $33.4 \mathrm{~b}$ & $33.4 \mathrm{c}$ & $31.4 \mathrm{~b}$ & $32.3 \mathrm{c}$ \\
\hline High Input & 3270 a & 2831 a & 4085 a & $4100 \mathrm{a}$ & $42.9 \mathrm{a}$ & $45.0 \mathrm{a}$ & $37.0 \mathrm{a}$ & $45.1 \mathrm{a}$ \\
\hline \multicolumn{9}{|l|}{ Organic } \\
\hline Recommended & $2879 \mathrm{~b}$ & $2678 \mathrm{a}$ & $3564 \mathrm{~b}$ & $3582 \mathrm{~b}$ & $34.1 \mathrm{~b}$ & $28.7 \mathrm{~d}$ & $30.0 \mathrm{~b}$ & $31.0 \mathrm{c}$ \\
\hline High Input & $2981 \mathrm{~b}$ & $2656 a$ & $3660 \mathrm{~b}$ & $3486 \mathrm{~b}$ & $42.7 \mathrm{a}$ & $42.3 \mathrm{~b}$ & $38.6 \mathrm{a}$ & $36.3 \mathrm{~b}$ \\
\hline $\mathrm{SE}^{++}$ & 114 & 87 & 65 & 122 & 0.97 & 0.98 & 0.80 & 0.68 \\
\hline & \multicolumn{4}{|c|}{ Weed Densities (Weeds/m²) } & \multicolumn{4}{|c|}{ Harvest Plant Density (Plants/m²) } \\
\hline \multicolumn{9}{|l|}{ Convent. } \\
\hline Recommended & $0.24 \mathrm{c}$ & $0.44 \mathrm{~b}$ & $0.03 \mathrm{~b}$ & $0.06 \mathrm{~b}$ & $30.8 \mathrm{c}$ & $31.8 \mathrm{c}$ & $29.6 \mathrm{~b}$ & $28.4 \mathrm{c}$ \\
\hline High Input & $0.11 \mathrm{c}$ & $0.27 b$ & $0.02 \mathrm{~b}$ & $0.04 \mathrm{~b}$ & $41.8 \mathrm{a}$ & $44.2 \mathrm{a}$ & $36.5 \mathrm{a}$ & $40.8 \mathrm{a}$ \\
\hline \multicolumn{9}{|l|}{ Organic } \\
\hline Recommended & $0.61 \mathrm{a}$ & $0.77 \mathrm{a}$ & $0.71 \mathrm{a}$ & $0.68 \mathrm{a}$ & $33.8 \mathrm{~b}$ & $28.5 \mathrm{~d}$ & $30.0 \mathrm{~b}$ & $25.9 \mathrm{~d}$ \\
\hline High Input & $0.40 \mathrm{~b}$ & $0.60 \mathrm{a}$ & $0.69 \mathrm{a}$ & $0.71 \mathrm{a}$ & $41.9 \mathrm{a}$ & $38.3 \mathrm{~b}$ & $35.8 \mathrm{a}$ & $35.1 \mathrm{~b}$ \\
\hline $\mathrm{SE}^{++}$ & 0.07 & 0.07 & 0.07 & 0.10 & 1.24 & 1.16 & 1.44 & 1.11 \\
\hline
\end{tabular}

+ Treatment means within the same column followed by the same letter are not significantly different according to Tukey's Studentized Range test (HSD) at $p \leq 0.05 .{ }^{++} \mathrm{SE}$ is the standard error of the mean for the farming system $\times$ input management interaction. 
Early plant density had significant farming system $x$ input management interactions in 2015, 2017 and 2018 but harvest plant density only had an interaction in 2018 (Table 3). Early plant density also had a farming system effect in 2016; whereas harvest plant density had a farming system effect in 2016 but no farming system effects in 2015 and 2017. Organic compared with conventional soybean mostly had similar early plant densities but organic soybean did have lower early plant densities with recommended and high inputs in 2016 and with high inputs in 2018 (Table 6). Organic compared with conventional soybean mostly had lower harvest plant densities except in 2017 when harvest densities were similar between their respective treatments (Table 6). Early plant densities had positive correlations with yield in 2015 (Table 4, $r=0.31, p=0.03$ ) and $2018(r=0.33, p=0.02)$; whereas harvest plant density only had a positive correlation with yield in $2018(r=0.39, p=0.01)$. Harvest index values only had a farming system effect in 2016 when conventional compared with organic soybean had greater values in their respective input treatments (Tables 3 and 7). Harvest index values, however, did not correlate with yield in 2016 but did correlate with yield in $2015(r=0.40, p=0.01)$.

Table 7. Harvest index, pods/plant, seeds/pod and seed weight of soybean in 2015, 2016, 2017 and 2018 under conventional and organic farming systems with recommended and high input management at a University Research Farm in central New York, USA.

\begin{tabular}{|c|c|c|c|c|c|c|c|c|}
\hline \multirow{2}{*}{$\begin{array}{l}\text { Treatment } \\
\text { Convent. }\end{array}$} & \multicolumn{4}{|c|}{ Harvest Index } & \multicolumn{4}{|c|}{ Pods/Plant (No.) } \\
\hline & 2015 & 2016 & 2017 & 2018 & 2015 & 2016 & 2017 & 2018 \\
\hline Recommended & $0.39 \mathrm{a}^{+}$ & $0.49 \mathrm{a}$ & $0.43 \mathrm{a}$ & - & $34.1 \mathrm{a}$ & $25.4 \mathrm{a}$ & $41.5 \mathrm{a}$ & $42.7 \mathrm{a}$ \\
\hline High Input & $0.38 \mathrm{a}$ & $0.47 \mathrm{a}$ & $0.42 \mathrm{a}$ & - & $22.5 \mathrm{~b}$ & $17.0 \mathrm{c}$ & $30.9 \mathrm{~b}$ & $28.1 \mathrm{c}$ \\
\hline \multicolumn{9}{|l|}{ Organic } \\
\hline Recommended & $0.39 \mathrm{a}$ & $0.42 \mathrm{~b}$ & $0.42 \mathrm{a}$ & - & $22.3 \mathrm{~b}$ & $22.4 \mathrm{~b}$ & $28.6 \mathrm{~b}$ & $38.0 \mathrm{~b}$ \\
\hline High Input & $0.39 \mathrm{a}$ & $0.42 \mathrm{~b}$ & $0.42 \mathrm{a}$ & - & $17.6 \mathrm{c}$ & $17.7 \mathrm{c}$ & $22.2 \mathrm{c}$ & $28.0 \mathrm{c}$ \\
\hline $\mathrm{SE}^{++}$ & 0.003 & 0.01 & 0.004 & - & 2.0 & 1.4 & 1.2 & 1.8 \\
\hline & \multicolumn{4}{|c|}{ Seeds/Pod (No.) } & \multicolumn{4}{|c|}{ Seed Weight (mg) } \\
\hline \multicolumn{9}{|l|}{ Convent. } \\
\hline Recommended & $2.16 \mathrm{~b}$ & $2.22 \mathrm{ab}$ & $2.31 \mathrm{c}$ & $2.36 \mathrm{a}$ & $144 \mathrm{c}$ & 192 c & $160 \mathrm{~d}$ & $185 \mathrm{c}$ \\
\hline High Input & $2.23 \mathrm{~b}$ & $2.28 \mathrm{a}$ & $2.38 \mathrm{~b}$ & $2.33 \mathrm{a}$ & $150 \mathrm{~b}$ & $200 \mathrm{~b}$ & $171 \mathrm{c}$ & $196 \mathrm{~b}$ \\
\hline \multicolumn{9}{|l|}{ Organic } \\
\hline Recommended & $2.35 \mathrm{a}$ & $2.18 \mathrm{~b}$ & $2.42 \mathrm{a}$ & $2.14 \mathrm{~b}$ & $174 \mathrm{a}$ & $225 \mathrm{a}$ & $184 \mathrm{a}$ & $236 \mathrm{a}$ \\
\hline High Input & $2.38 \mathrm{a}$ & $2.15 b$ & $2.44 \mathrm{a}$ & $2.06 \mathrm{~b}$ & $174 \mathrm{a}$ & $222 \mathrm{a}$ & $186 \mathrm{a}$ & $239 a$ \\
\hline $\mathrm{SE}^{++}$ & 0.05 & 0.06 & 0.01 & 0.02 & 2.84 & 2.80 & 1.50 & 1.91 \\
\hline
\end{tabular}

\footnotetext{
+ Treatment means within the same column followed by the same letter are not significantly different according to Tukey's Studentized Range test (HSD) $p \leq 0.05 .{ }^{++}$SE is the standard error of the mean for the farming system $\times$ input management interaction.
}

Weed densities at the full pod stage (R5) had farming system $\mathrm{x}$ input management interactions in 2015 and 2018 and farming system effects in 2016 and 2017 (Table 3). Organic compared with conventional soybean had greater weed densities in all respective input comparisons (Table 6). Input management, however, had no significant effect on weed density in 2016 and 2017. Weed densities were surprisingly low in all years averaging only $\approx 0.65$ weeds $/ \mathrm{m}^{2}$ in organic soybean and $\approx 0.20$ weeds $/ \mathrm{m}^{2}$ in conventional soybean. Despite low weed interference, weed densities had negative correlations with yield in 2015 (Table 4, $r=-0.36, p=0.01), 2017(r=-0.53, p \leq 0.001)$ and $2018(r=-0.36, p=0.01)$.

All three yield components had significant main effects or interactions between farming systems and input management in all 4 years of the study (Table 3). Pods/plant had farming system $x$ input management interactions in 2015 and 2018 and a farming system effect in 2016 and 2017. Pods/plant also had input management effects in 2016 and 2017. Organic compared with conventional soybean had lower pods/plant in most input comparisons except in 2016 and 2018 with high inputs when organic and conventional soybean had similar pod numbers in their respective management treatments (Table 7). High input compared with recommended input management had fewer pods/plant in both farming systems in all years. Seed weight had a farming system $\times$ input management interaction in all years (Table 3). Conventional soybean had greater seed weight in high input compared with 
recommended input management in all years, whereas organic soybean had similar seed weight between input treatments in all years (Table 7). Seeds/pod, which did not show a consistent effect between farming systems, had a farming system effect in 2015, 2016 and 2018 and a farming system $\mathrm{x}$ input management interaction in 2017. Organic compared with conventional soybean had mostly greater seeds/pod in 2015 and 2017 but mostly lower seeds/pod in 2016 and 2018 (Table 7). Yield components did not have consistent correlations with yield across years in this study with no yield components correlating with yield in 2015 and 2016 (Table 4). Pods/plant had a positive correlation with yield in 2017 ( $r=0.52, p \leq 0.001)$ but no correlation in 2018. Seeds/pod had a negative correlation with yield in $2017(r=-0.31, p=0.03)$ and a positive correlation with yield in $2018(r=0.42, p=0.01)$. Seed weight did have consistent negative correlations with yield in $2017(r=-0.44, p=0.001)$ and in $2018(r=-0.31, p=0.03)$.

\section{Discussion}

Organic compared with conventional soybean yield was more competitive in our study compared to other studies in which $15 \%$ to $40 \%$ lower yield has been reported [4-7,10,11]. The similar yield between organic and conventional soybean with recommended inputs during the first 2 years of our study agree with the study in Iowa, USA in which soybean yield was similar during the transition years [8]. In our study, however, organic compared with conventional soybean yield averaged $\approx 11 \%$ lower in the next 2 years, whereas in the Iowa study organic and conventional soybean yield remained similar. Organic soybean did not show a yield response to high input management (33\% greater seeding rate and the addition of an organic seed treatment in high input management) in any year of the study. Our results thus contrast with a study in North Carolina, USA that found that greater seeding rates (556,000 seeds/ha) reduced weed densities and increased yield of organic soybean [13]. Our study, however, agrees with an organic soybean study in Minnesota, USA, which reported similar yield with seeding rates of 395,000 and 543,600 seeds/ha [20]. Also, the use of an organic seed treatment did not influence yield. Our hypothesis was that the use of an organic seed treatment would result in more rapid and greater soybean emergence rates [21], which would improve early season competitiveness of the crop against weeds, thereby increasing yield. The early plant establishment rate, however, did not differ in organic soybean between high inputs $(\approx 81 \%)$ and recommended inputs $(\approx 83 \%)$. Consequently, organic soybean with recommended compared with high inputs had similar weed densities in 3 of 4 years and similar yield in all years. Conventional soybean also did not show a yield response to high inputs, except for the $\approx 9 \%$ yield increase in 2015 .

Organic compared with conventional soybean had similar early plant densities at the 2nd true leaf stage (V2), except in 2016 and in 2018 with high input management. Our early plant density measurements occurred after tine weeding or rotary hoeing so apparently there was minimal damage by these operations to emerging organic soybean seedlings in most years. Nevertheless, the lower early plant densities in organic compared with conventional soybean in 2016, a year with very dry spring conditions, were probably associated with the aggressive rotary hoeing operation, as indicated by more visible plant damage.

Lower plant densities in organic soybean have been reported to increase weed interference in organic soybean, leading to lower yield [14,15]. Early and harvest plant densities, however, did not differ between organic and conventional soybean in their respective input treatments in 2017 when organic compared to conventional soybean yield was $\approx 11 \%$ lower. In 2018 , however, organic compared with conventional soybean had $\approx 20 \%$ lower early plant densities in the high input treatment and $\approx 15$ to $\approx 18 \%$ lower harvest plant densities in both input treatments. Early and harvest plant densities also had positive correlations with yield in 2018. Consequently, lower plant densities may have been a contributing factor to the $\approx 11 \%$ lower organic soybean yield in 2018 . A previous study in the Northeast USA with conventional soybean, however, indicated that the threshold harvest plant density below which yield losses occur is $\approx 25$ plants $/ \mathrm{m}^{2}$ [22]. Organic soybean with recommended inputs had early plant densities of 31.0 and harvest plant densities of 25.9 plants $/ \mathrm{m}^{2}$ in 2018 , so lower plant densities 
may not have been a factor in the lower yield. Furthermore, soybean shows a tremendous ability to compensate for lower early plant densities by producing more side branches with pods, resulting in similar yield across a broad seeding rate range [23]. A study at the same experimental site of this study reported similar yield at seeding rates from 358,000 to 588,000 seeds/ha because soybean produced $\approx 10$ more pods/plant at the lower seeding rate [24]. Another study at the same experimental site, however, reported that soybean did not increase side branches or pods/plant when $10 \%$ of the plants were removed at the sixth leaf stage (V6), resulting in yield losses of $\approx 5 \%$ at similar seeding rates used in this study [25]. Consequently, some yield losses may have occurred in organic soybean in 2018 because of lower soybean densities, associated with the close cultivation at the 4th leaf stage.

Weed interference, however, is usually the prime factor associated with the $15-40 \%$ lower organic compared with conventional soybean yield reported in the literature [5-7,10-12]. Organic compared with conventional soybean had greater weed densities in 2017 and 2018 , the years of $\approx 11 \%$ lower yield but weed densities in organic soybean averaged only $\approx 0.70$ weeds $/ \mathrm{m}^{2}$ across management treatments. Furthermore, most of the weed infestations were confined to isolated areas of the plots with most of the plot area having very few weeds. Soil conditions were extremely wet from late May through mid-July in 2017, the time for repeated mechanical weed control practices in soybean. The wet spring and early summer conditions, however, did not lead to more weed interference and much lower yield in organic soybean compared to years with drier conditions, as reported in other studies $[5,6,10]$. In fact, the wet conditions in 2017 compared to the dry conditions in 2016 resulted in much taller and more robust organic soybean plants, which appeared to make soybean more competitive with weeds, as evidenced by the very low weed densities in conventional soybean in 2017. The 2017 growing season, however, was only the 3rd growing season of organically-managed crops in this study so perhaps weed interference will increase in future years and become more difficult to control when wet spring and early summer conditions prevail.

Organic soybean with recommended and high inputs had similar weed densities in 3 of the 4 years of our study, despite the $\approx 125,000$ seeds/ha greater seeding rate. Again, this contrasts with a study in North Carolina, USA that reported that high seeding rates reduced weed densities in organic soybean [13] but agrees with the Minnesota study that reported that high seeding rates did not reduce weed densities [20]. Weed densities did have a strong negative correlation with yield in 2017 and a negative correlation with yield in 2018 but it is doubtful that $\approx 0.70$ weeds $/ \mathrm{m}^{2}$ at the end of the critical weed-free period would be responsible for the entire $\approx 11 \%$ lower yield in organic compared with conventional soybean.

Another factor that may contribute to the $\approx 11 \%$ yield difference between organic and conventional soybean in 2017 and 2018 is the difference in row spacing between the two treatments. A meta-analysis study indicated that soybean showed a $240 \mathrm{~kg} /$ ha yield decrease when row spacing increased from 0.38 to $0.76 \mathrm{~m}$ in northern latitudes [26]. In fact, in a previous row spacing study at the same experimental site, conventional soybean at $0.76 \mathrm{~m}$ compared with $0.38 \mathrm{~m}$ row spacing yielded $8.3 \%$ lower [24]. Interestingly, in another study at this same experimental site from 1994 to 1996, conventional soybean in $0.38 \mathrm{~m}$ row spacing with a combination of herbicides for weed control compared with conventional soybean in $0.76 \mathrm{~m}$ row spacing with the use of rotary hoeing and inter-row cultivations for weed control yielded $4 \%$ greater across the 3 years, despite similar weed densities $\left(\approx 1.3\right.$ weeds $\left./ \mathrm{m}^{2}\right)$ between treatments [27]. Organic and conventional soybean in the present study, however, had similar yield in 2015 and 2016, despite wider row spacing, so it is not clear if wider row spacing was a factor in the $\approx 11 \%$ lower organic soybean yield in 2017 and 2018. Nevertheless, future research may wish to examine the impact of wider row spacing on the yield penalty associated with organic soybean production.

Organic compared with conventional soybean had fewer pods/plant in most comparisons except in 2016 and 2018 when pod numbers were similar between farming systems with high inputs. Organic compared with conventional soybean had lower harvest plant densities in the 2016 and 2018 comparisons so it was somewhat surprising that organic soybean did not have more pods/plant than its conventional counterpart. Furthermore, despite having similar harvest plant densities with 
recommended inputs in 2015 and with both management inputs in 2017, organic compared with conventional soybean had fewer pods/plant. Again, the pod number results were somewhat surprising because both soybean organic varieties compared to the conventional variety were rated as having a wider canopy width or more branching capability by the seed company [28]. Another factor for the mostly lower pod numbers in organic soybean may be that most of the crop damage by mechanical weed control occurred at the 4th leaf stage (V4) so organic soybean may not have responded with more side branches with more pods [25]. Organic compared with conventional soybean did have a consistent $8 \%$ to $9 \%$ greater seed weight in all years of the study. Consequently, organic and conventional soybean yielded the same in 2015 and 2016 because fewer pods/plant in organic soybean were offset by more seeds/pod and greater seed weight in 2015 and by greater seed weight in 2016. In 2017, however, when harvest plant densities were similar between cropping systems, organic compared with conventional soybean yielded $\approx 11 \%$ lower because greater seeds/pod $(0.07)$ and greater seed weight $(\approx 20 \mathrm{mg}$ ) could not offset fewer pods/plant $(\approx 11)$. In 2018 , organic compared with conventional soybean yielded $\approx 11 \%$ lower because of lower harvest plant densities, fewer pods/plant and fewer seeds/pod, which were not offset by its greater seed weight $(\approx 48 \mathrm{mg})$.

As expected, recommended input compared with high input management had more pods/plant in organic and conventional soybean in all respective input comparisons in all years of the study. High compared with recommended input management in conventional soybean had greater seed weight in all years, which is consistent with some seeding rate studies reporting increased seed weight at greater soybean densities but not in other studies [29]. When averaged across years, conventional soybean with high compared with recommended inputs had $\approx 32 \%$ fewer pods/plant but $\approx 5 \%$ greater seed weight. In contrast, organic soybean with high compared with recommended inputs had $23 \%$ fewer pods/plant but similar seed weight. Some of the increase in seed weight in conventional soybean with high compared with recommended inputs may be associated with the supposed benefits to plant health by the fungicide application of Pyraclostrobin [30]. Nevertheless, it is not completely clear why organic soybean mostly had fewer pods/plant when compared with conventional soybean; and why seed weight or seeds/pod did not increase in organic soybean in the high input treatment, which had fewer pods/plant. Very few studies, if any, have examined the yield component responses by organic soybean to management practices so this may be an area for future research.

\section{Conclusions}

Organic compared with conventional soybean performed well (similar yield to $11 \%$ lower) in this study across a range of climatic conditions. Weed infestations were very manageable in organic soybean with timely mechanical weed control, even in years with wet spring conditions. Weed infestations, however, were quite low at this experimental site at the onset of the study in 2015. Future research may wish to focus on fields where weed infestations are greater, perhaps on fields of growers who are contemplating a transition to organic soybean production. In addition, researchers could evaluate organic soybean seeding rates on fields with higher weed infestations to determine if higher seeding rates can reduce weed infestations, thereby increasing organic soybean yield. Insect and pathogens, which are more difficult to control in organic compared with conventional soybean [31], were not highly prevalent in our study. Future research on organic soybean may wish to select fields with a known high insect or pathogen presence to determine how organic soybean performs under these conditions.

Author Contributions: Conceptualization, W.C.; data curation, W.C.; formal analysis, J.C.; funding acquisition, M.S.; investigation, W.C.; methodology, W.C.; writing-original draft, W.C.; writing-review \& editing, J.C. and M.S.

Acknowledgments: This project was partially supported by the U.S. Department of Agriculture Cooperative State Research, Education and Extension Service through New York Hatch Project 1257322. Pioneer Hi-Bred supplied all the seed for the study.

Conflicts of Interest: The authors have no conflict of interest. 


\section{References}

1. USDA Survey. 2016 Certified Organic Survey. Available online: https://downloads.usda.library.cornell.edu/ usda-esmis/files/zg64tk92g/70795b52w/4m90dz33q/OrganicProduction-09-20-2017_correction.pdf (accessed on 12 June 2019).

2. USDA ERS. The Profit Potential of Certified Organic Field Crop Production. Available online: https: //www.ers.usda.gov/webdocs/publications/45380/53409_err188.pdf?v=0 (accessed on 8 July 2019).

3. USDA ERS. Growing Organic Demand Provides High-Value Opportunities for Many Types of Producers. Available online: https://www.ers.usda.gov/amber-waves/2017/januaryfebruary/growing-organic-demandprovides-high-value-opportunities-for-many-types-of-producers/ (accessed on 8 July 2019).

4. McBride, W.D.; Greene, C.R. Organic data and research from the ARMS survey: Findings on competitiveness of the organic soybean sector. Crop Manag. 2013, 12. [CrossRef]

5. Posner, J.L.; Baldock, J.O.; Hedtcke, J.L. Organic and Conventional Production Systems in the Wisconsin Integrated Cropping Systems Trials: I. Productivity 1990-2002. Agron. J. 2008, 100, 253-260. [CrossRef]

6. Coulter, J.A.; Delbridge, T.A.; King, R.P.; Sheaffer, C.C. Productivity, economic and soil quality in the Minnesota Variable-Input Cropping Systems Trial. Crop Manag. 2013. [CrossRef]

7. Archer, D.W.; Jaradat, A.A.; Johnson, J.M.F.; Lachnicht-Weyers, S.; Gesch, R.W.; Forcella, F.; Kludze, H.K. Crop productivity and economics during the transition to alternative cropping systems. Agron. J. 2007, 99, 1538-1547. [CrossRef]

8. Delate, K.; Cambardella, C.A. Agroecosystem performance during transition to certified organic grain production. Agron. J. 2004, 96, 1288-1298. [CrossRef]

9. Delate, K.; Cambardella, C.; Chase, C.; Johanns, A.; Turnbull, R. The long-term agroecological research (LTAR) experiment supports organic yield, soil quality and economic performance in Iowa. Crop Manag. 2013. [CrossRef]

10. Cavigelli, M.A.; Teasdale, J.R.; Conklin, A.E. Long-term agronomic performance of organic and conventional field crops in the mid-Atlantic region. Agron. J. 2008, 100, 785-794. [CrossRef]

11. White, K.E.; Cavigelli, M.A.; Conklin, A.E.; Rasman, C. Economic Performance of Long-term Organic and Conventional Crop Rotations in the Mid-Atlantic. Agron. J. 2019, 111, 1-3. [CrossRef]

12. Carkner, M.K.; Entz, M.H. Growing environment contributes more to soybean yield than cultivar under organic management. Field Crops Res. 2017, 20, 42-51. [CrossRef]

13. Teasdale, J.R.; Mangum, R.W.; Radjalrosjmam, J.; Cavigelli, M.A. Weed seedbank dynamics in three organic farming crop rotations. Agron. J. 2014, 96, 1429-1435. [CrossRef]

14. Place, G.T.; Reberg-Horton, S.C.; Dunphy, J.E.; Smith, A.N. Seeding rate effects on weed control and yield for organic soybean production. Weed Tech. 2009, 23, 497-502. [CrossRef]

15. Liebert, J.A.; Ryan, M.R. High planting rates improve weed suppression, yield and profitability on organically-managed soybean, no-till planted soybean. Weed Technol. 2017, 31, 536-549. [CrossRef]

16. Cox, W.J.; Cherney, J.H. Agronomic comparisons of conventional and organic maize during the transition to an organic cropping system. Agronomy 2018, 8, 113. [CrossRef]

17. Cox, W.J.; Cherney, J.H.; Sorrells, M.E. Organic Compared with Conventional Wheat Had Competitive Yield during the Early Years of Organic Production in the Northeast USA. Agronomy 2019, 9, 380. [CrossRef]

18. Van Acker, R.C.; Swanton, C.J.; Weise, S.F. The Critical Period of Weed Control in Soybean [Glycine max (L.) Merr.]. Weed Sci. 1993, 41, 194-200. [CrossRef]

19. Doss, B.D.; Pearson, R.W.; Rogers, H.T. Effect of soil water stress at various growth stages on soybean yield. Agron. J. 1974, 66, 297-299. [CrossRef]

20. Coulter, J.A.; Sheaffer, C.C.; Haar, M.J.; Wyse, D.L.; Orf, J.H. Soybean cultivar response to planting date and seeding rate under organic management. Agron. J. 2011, 103, 1223-1229. [CrossRef]

21. Kuchlan, P.; Ansari, M.; Kuchlan, M.M.M. Efficient application of Trichoderma viride on soybean [Glycine $\max ($ L.) Merrill] seed using thin layer polymer coating. Legume Research. 2018. [CrossRef]

22. Cox, W.J.; Cherney, J.H. Location, variety and seeding rate interactions with soybean seed-applied insecticide/fungicides. Agron J. 2011, 103, 123-128. [CrossRef]

23. Suhre, J.; Weidenbenner, N.H.; Rowntree, S.C.; Wilson, E.W.; Naeve, S.L.; Conley, S.P.; Casteel, S.N.; Diers, B.W.; Esker, P.D.; Specht, J.E.; et al. Soybean yield partitioning changes revealed by genetic gain and seeding rate interactions. Agron. J. 2014, 106, 1631-1642. [CrossRef] 
24. Cox, W.J.; Cherney, J.H. Growth and yield responses of soybean to row spacing and seeding rate. Agron. J. 2011, 103, 123-128. [CrossRef]

25. Cox, W.J.; Cherney, J.H.; Shields, E. Soybeans compensate at low seeding rates but not at high thinning rates. Agron. J. 2010, 102, 1238-1243. [CrossRef]

26. Andrade, J.F.; Rattalino Edreira, J.I.; Mourtzinis, S.; Conley, S.P.; Ciampitti, I.A.; Dunphy, J.E.; Gaska, J.M.; Glewen, K.; Holshouser, D.L.; Kandel, H.J.; et al. Assessing the influence of row spacing on soybean using experimental and producer survey data. Fields Crops Res. 2019, 230, 98-106. [CrossRef]

27. Cox, W.J.; Singer, J.S.; Shields, E.J.; Waldron, K.; Bergstrom, G.C. Agronomics and Economics of different weed management systems in corn and soybean. Agron. J. 1999, 91, 585-591. [CrossRef]

28. Pioneer Brand Products for Northeastern Minnesota and Wisconsin. 2015-2016. Available online: http: //www.croppingcentralllc.com/pdf/soybeans/2015-2016-corn-soybean-product-guide.pdf (accessed on 8 July 2019).

29. Carciochi, W.D.; Schwalbert, R.; Andrade, F.H.; Corassa, G.M.; Carter, P.; Gaspar, A.P.; Schmidt, J.; Ciampitti, I.A. Soybean seed yield response to plant density by yield environment in North America. Agron. J. 2019, 111, 1923-1932. [CrossRef]

30. Mahoney, K.J.; Vyn, R.J.; Gillard, C.L. The effect of pyraclostrobin on soybean plant health, yield and profitability in Ontario. Can. J. Plant Sci. 2015, 95, 285-292. [CrossRef]

31. Harman, G.L.; Pawlowski, M.L.; Herman, T.K.; Eastburn, D. Organically grown soybean production in the USA: Constraints and management of pathogens and insect pests. Agronomy 2016, 6, 16. [CrossRef]

(C) 2019 by the authors. Licensee MDPI, Basel, Switzerland. This article is an open access article distributed under the terms and conditions of the Creative Commons Attribution (CC BY) license (http://creativecommons.org/licenses/by/4.0/). 